\title{
DEFINING INEQUALITY
}

Is there a link between inequality and access to land? Although we tend to think that inequality depends on income disparities, this text -part of a long-term research project conducted by the Buell Center at Columbia University- shows us that housing is one of its most powerful engines. Certain practices of architecture, therefore -at least according to the essay's authors- might be better understood as "the art of inequality."

KEYWORDS - housing, real estate, land, crisis, United States

The received differences between 'house' and 'housing' are not innocent. They have been constructed by complex interactions between governments, finance, corporations, popular media, and architecture, among other forces. Since 2012, House Housing: An Untimely History of Architecture and Real Estate, a research project developed by the Temple Hoyne Buell Center for the Study of American Architecture at Columbia University, has attempted to expose these connections through exhibitions, publications, public programs, and a comprehensive website (house-housing.com).

One outcome of this research is the book The Art of Inequality: Architecture, Housing, and Real Estate - A Provisional Report. We are here sharing a translation of its first chapter, "Defining Inequality." It serves as an introduction to the relationship between land and inequality and illuminates how architecture is an active, rather than a passive, mediator between the two.

\section{DEFINING INEQUALITY}

What is inequality? Typically, inequality is defined by a combination of economic measures referring to income and wealth. Such inequality is inseparable from social disparities of other kinds, however, an interdependency that is particularly apparent in the provision of housing.

More than just a building type or a market sector, housing is a primary architectural act. It begins when a line is drawn that separates inside from outside, and ultimately, one house from another. Under the rule of real estate development, that relation is structurally unequal. This is the art of inequality. 


\section{Reinhold Martin}

\author{
Director \\ Temple Hoyne Buell Center for the Study \\ of American Architecture \\ Columbia University, New York, USA
} (EDITOR)

\section{Jacob Moore}

\author{
Assistant Director \\ Temple Hoyne Buell Center for the Study \\ of American Architecture \\ Columbia University, New York, USA \\ (AUTOR, EDITOR)
}

\section{Susanne Schindler}

\author{
Associate Research Scholar \\ Temple Hoyne Buell Center for the Study \\ of American Architecture \\ Columbia University, New York, USA \\ (AUTOR, EDITOR)
}

\section{AFFORDABILITY, INCOME, AND WEALTH}

Following the neoliberal turn in the early 1970s and the 'Great Recession' more recently, inequalities of all types have become increasingly legible in exclusively financial terms. These terms, including their inherent occlusions and limitations, occupy an outsize proportion of our collective imagination. Speculative real estate development -just such a concept-is premised on differences in value, particularly in housing. The notion of affordability, therefore, is one of several possible openings into the complex relationship to architecture and the primary vehicle through which housing is produced and priced in the United States -real estate.

Affordability is generally determined by whether one's income can pay for essential goods and services without causing undue financial hardship. Housing is one of these essential goods. Income inequality describes the relative difference in income between specific groups. It is no accident that both affordability and income inequality are much discussed in the United States today: incomes are diverging at an accelerated rate, and housing is increasingly unaffordable not only for those people on the (expanding) lower end of the spectrum. According to u.s. tax data in 1976, the 1 percent of households earning the highest pre-tax incomes received 9 percent of the nation's total income. By 2012, their share had increased to over 22 percent (Piketty, Saez, 2003). In 2014, according to the National Low-Income Housing Coalition, 49 percent of renters across the United States had a housing cost burden, and for 27 percent it was deemed "severe" (National Low-Income Housing Coalition 2015:4).

Another example that brings together growing income inequality and unaffordability, this one focusing on individuals within a single company as opposed a nation's households, is perhaps more telling. As the business magazine Quartz put it in 2014: "It takes the average McDonald's worker seven months to earn what its CEO makes in just a single hour" (King, Ferdman, 2013). This calls to mind studies comparing the purchasing power, measured in Big Macs, of McDonald's hourly wages around the globe. McDonald's entry-level workers in the United States earned 2.41 Big Macs per hour of work, while their counterparts in India earned 0.35 of a Big Mac hourly, and those in Japan earned 3.09 (Ashenfelter, 2012).

In parallel, inequality of wealth -including assets such as real estate- is reaching new heights. In the U.S. in 2013, upper-income families' median wealth was almost seven times 


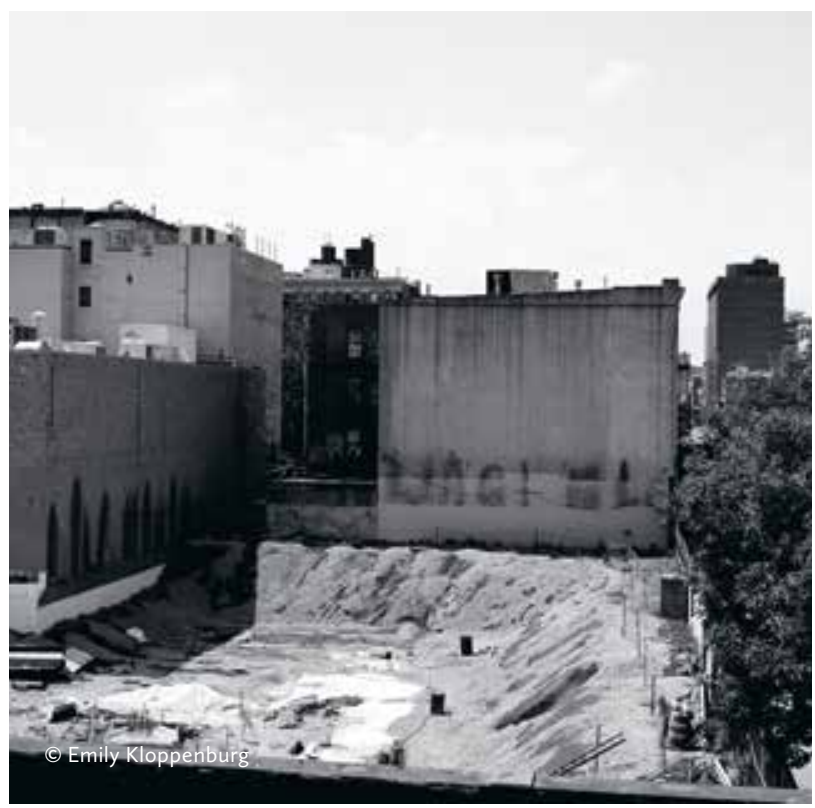

that of middle-income families, and almost 70 times that of low-income families. These are the highest levels of wealth inequality that have been recorded by the Federal Reserve since they began collecting data thirty years ago ${ }^{1}$ (Fry, Kochhar, 2014). On a global scale, according to a 2014 study, the wealth of the world's eighty-five most affluent individuals is equivalent to that of the poorest 3.5 billion. ${ }^{2}$ Accordingly, in the realm of housing, discussions of inequality in the United States no longer refer primarily to physical factors -inadequate size or a lack of basic services like running water or electricity- but to financial aspects -affordability, and the unequal distribution of wealth according to housing ownership.

Today, in the United States, housing constitutes roughly half of all household wealth (lacoviello, 2011). Both through private investment and expenditures on utilities and rent, housing contributes 17 percent of GDP (NAHB, 2014). Geographers Manuel Aalbers and Brett Christophers write: "It is of immense significance that in many capitalist societies residential property is the largest individual wealth/asset class although at the same time many -in some countries most- households own no residential property whatsoever. As such, it is in housing that the vast wealth inequalities of capitalist societies... are often most visible and most material" (Aalbers y Christophers, 2014).

\section{REAL ESTATE DEVELOPMENT}

The concept and practice of real estate development are based on certain assumptions. If these assumptions are less than a surprise, it reveals the extent to which the logic of real estate development under capitalism has taken hold of the way we see the world. This logic has led us to consider principles constructed over time and under specific historical circumstances as axiomatic, self-evident truths (See Martin, Moore, Schindler, 2015). The first hegemonic assumption is that space and its underlying land can be sub-divided and owned: that individuals or corporations can hold a title to a circumscribed piece of the planet's surface, along with the space above or below it. This ownership, then, entitles one to occupation, use, and exploitation of any natural resources in that space. A second assumption fundamental to real estate is that space can be sold and traded (See Martin, Moore, Schindler, 2015). In other words, space is a commodity like any other -such as a car, a sweater, or a gold ingot. As property, space is not passed on solely through familial bonds, but is freely tradable through contractual arrangements (See Martin, Moore, Schindler, 2015). A third assumption is that the price of a piece of space to be sold, or the rent to be charged for its use, is determined by a market, i.e. by supply and demand, and not through other mechanisms (See Martin, Moore, Schindler, 2015).

\footnotetext{
1 Here upper income is defined as household incomes, adjusted for size, that are more than twice the national median.

2 Further, "The top 1 percent controls almost 50 percent of global wealth and the top 10 percent owns 83 percent of the world's wealth. In contrast, the bottom half of the population together possess less than 2 percent of global wealth" (Dreier, et al., 2014:14)
} 
Only more recently has a fourth and final assumption developed that, as a property, land can become a financial instrument (See Martin, Moore, Schindler, 2015). That is, by establishing space as collateral to be borrowed against, as the security for a loan, and allowing for the debt on that property to be resold to other creditors, what is in principle the most tangible and real form of property, has become the most fungible.

Under this hegemony, real estate development is fundamentally speculative. It is premised on the rise in value in a piece of land or property, in the expectation that its resale value be higher than the original payment made (See Martin, Moore, Schindler, 2015). Thus, for most forms of real estate development, a property's exchange value (how much its sale will bring on the market) is more important than its use value (what functional benefit it brings to its residents). These categories are not clearly separable, and in the case of an owner who occupies the property, the two goals overlap. ${ }^{3}$ Because market value is nevertheless considered of principal importance, homeownership has often been promoted as a key defense against both income and wealth inequality. The premise is that the value of property is expected to appreciate, enabling households to accumulate wealth and borrow against said wealth to provide liquidity. ${ }^{4}$ In practice, this has not always played out positively. In the United States, which has a comparatively high homeownership rate, this became especially conspicuous during the mortgage crisis of 2009. Between 2005 and 2010 , U.s. housing wealth decreased by $\$ 8.2$ trillion, by which time mortgage debt stood at 163 percent of home equity. ${ }^{5}$ This loss of housing wealth disproportionately affected low-income homeowners (Joint Center for Housing Studies, The State of the Nation's Housing, 2010).

\section{IN TERMS OF HOUSING}

A largely unregulated housing market will not serve those households who are unable to pay market rent. The State, therefore, remains the de facto guarantor, both directly and indirectly, of a social safety net. In the United States, federal, state, and local governments have taken up numerous strategies in the attempt to guide or define the intersection of real estate development and housing: building codes and zoning, rent regulation, anti-discrimination legislation, direct provision, direct and indirect subsidies, vouchers, insured mortgages, and more.

The ambiguities and contradictions of these strategies are best illustrated by governmental programs' use of the term

\footnotetext{
3 The concepts of exchange value and use value are generally associated with the work of Karl Marx. They are still valuable today, despite the fact that the two concepts are perhaps not so easily separable, but rather codependent. For a recent elaboration in terms of housing, see Massey, et al., 2013:8.

4 This premise presumes that ownership provides a greater degree of insulation from rising housing costs than renting. See U.s. Department of Housing and Urban Development, 2006.

5 Statistics were taken from the 2010 study due to its proximity to the housing crisis and focus therein. For more recent statistics, see the 2015 study at http:// www.jchs.harvard.edu/sites/jchs.harvard.edu/files/ jchs-sonhr-2015-full.pdf.
} 
"affordable housing" itself (See Martin, Moore, Schindler, 2015). The U.S. Department of Housing and Urban Development defines housing as affordable when rent or mortgage payments as well as utilities are not higher than 30 percent of a household's pre-tax income. By this definition, only 37 percent of U.S. households lived in affordable housing in 2010. ${ }^{6}$ As with the 'Big Macs per hour' example, the link between income and affordability can be illustrated through the concept of a housing wage -that is, the minimum hourly wage a full-time worker would need in order to spend no more than 30 percent of his or her income on a rental unit at Fair Market Rent (FMR). ${ }^{7}$ In 2015, the average national housing wage for a two-bedroom unit was $\$ 19.35$ while the national minimum wage was $\$ 7.25$. In other words, a household earning minimum wage would need to work more than two and a half full-time jobs to afford an average two-bedroom rental (Bolton, Bravve, Miller, Crowley y Errico, 2015). In the San Francisco and New York City metropolitan areas, where levels of income inequality are some of the country's highest, it takes more than three. ${ }^{8}$

Despite technically pertaining to all income levels, 'affordable housing' is used in practice to describe housing produced and priced through governmental incentives, usually targeted to groups below the Area Median Income or A MI. '. 'Affordable housing' can be developed by for-profit and non-profit entities, and is often also described as 'workforce housing' or 'subsidized housing'. Among other initiatives, funding can come through state or municipal bonds, housing trust funds, or Low-Income Housing Tax Credits (LIHTC) allotted by the Internal Revenue Service to the states. Given the market-driven nature of the programs, the income- and price-restrictions (elements of the perceived 'affordability') are not permanent. Their expiration can come as early as 15 years after completion (the minimum stipulated by LIHTC), or as late as 50 years (the goal set by the state of Oregon).

'Affordable housing' is typically contrasted with 'market-rate housing,' housing that is developed and sold or leased -ostensibly- without governmental regulation or subsidies.

6 According to hud, affordable housing is "In general, housing for which the occupant(s) is/are paying no more than 30 percent of his or her income for gross housing costs, including utilities." (u.s. Department of Housing and Urban Development, 2015a) Housing scholars have suggested that this measure of affordability is too limited to address the implications of the cost of housing on overall household budget. (Stone, 2013:103) For a discussion of how affordability criteria have evolved and what their limits are, see Pivo, 2013.

7 Fair Market Rent represents the $40^{\text {th }}$ percentile of rents (including contract rent and utilities) for typical units of standard quality. They are set annually by the us Department of Housing and Urban Development (HUD) for different metropolitan areas.

8 Information on income inequality in these areas comes from Berube and Holmes, 2015.

9 Each year, HUD publishes household income limits that are used to determine eligibility for housing subsidies administered at various levels of government. These limits are based on estimates, adjusted for family size, of the median family income for designated metropolitan and non-metropolitan areas. The resulting Area Median Income (AMI) estimates enable families' incomes to be expressed as a percentage of the median for their area. Families earning no more than 80 percent of ami are typically considered to be low-income and those earning no more than 50 percent of ami are considered extremely low-income. (U.S. Department of Housing and Urban Development, 2015b) 


\section{"The first hegemonic assumption is that space and its underlying land can be \\ sub-divided and owned: that individuals or corporations can hold a title to a circumscribed piece of the planet's surface, along with the space above or below it."}

While neither price nor eligibility is regulated, marketrate housing benefits from tax breaks which amount to governmental subsidies of their own. The Mortgage Interest Deduction, for instance, allows homeowners an income tax deduction of interest paid on the debt on their primary residence; in 2014, this amounted to a tax expenditure of \$101.5 billion and, since lower-income households do not make enough to afford this deduction, primarily benefitted upper-income households ${ }^{10}$ (Office of Management and Budget, 2014).

In contrast to the malleable and highly contingent terms affordable and market-rate, 'public housing' refers specifically to that which is developed, owned, and operated by the public sector. In the United States, municipal housing authorities take the local lead, but are regulated and funded by the federal government. This model of housing provision was formalized in the 1937 Housing Act. It was originally conceived to counterbalance the private market and help alleviate the housing shortage through supply, with the additional ambition of demonstrating higher design and construction standards (See Martin, Moore, Schindler, 2015). Due to pressure from a private sector in fear of competition, however, the program ended up exclusively targeting households at the low end of the income spectrum, today generally defined as making not more than 60 percent of the AMI. ${ }^{11}$ This led in many cases to the financial and social problems (and their consequent stigmas) with which the program has become associated. ${ }^{12}$

In the early 1970s, federal policy regarding public housing shifted from new construction to a voucher system allowing eligible households to rent from private landlords. The aim

\footnotetext{
10 Of the estimated $\$ 270$ billion the federal government spends annually on housing, approximately $\$ 195$ billion is spent on tax subsidies for homeowners. In comparison, the government spends approximately $\$ 40$ billion annually on means-tested housing subsidies (such as the public housing and Housing Choice Voucher programs) and $\$ 6$ billion on the LIHTC program (Collinson, et al., 2015). 11 For a definition of AMI, see footnote 9.

12 "To overcome opposition from the real estate industry, advocates for public housing agreed to have the program designed so that it would not compete with the private housing market. This meant that families eligible for public housing would have incomes far below the level necessary to secure decent housing in the private market. The concentration of very low-income families in public housing is widely considered a source of many of public housing's most dire problems, including its difficulty meeting operating costs and the myriad issues associated with concentrated poverty" (Schwartz, 2010:105).
} 


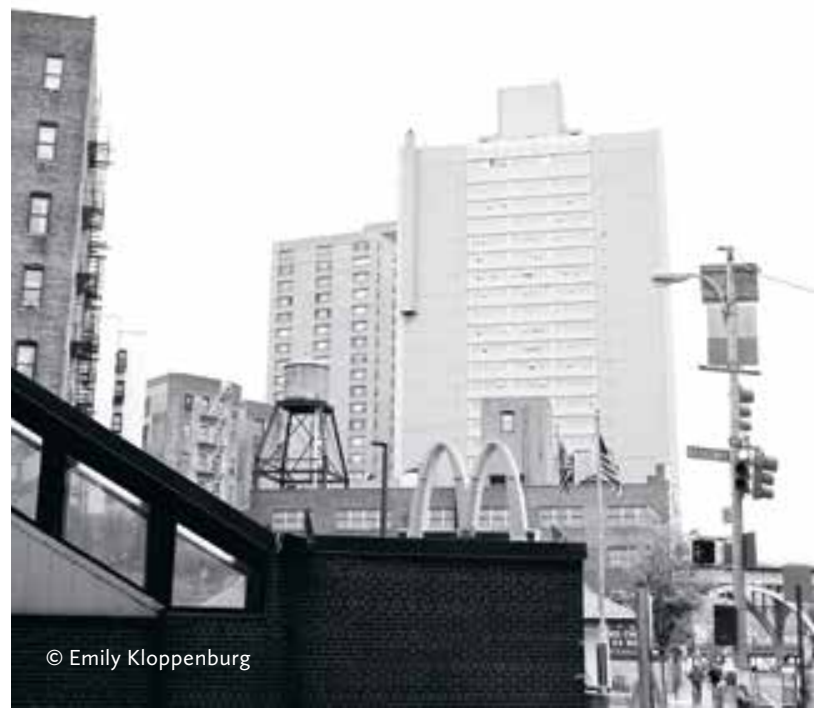

was not only to work against the concentration of poverty in public housing developments, but to support market-driven initiatives and end the federal government's direct role in housing development. A further restriction to public housing was introduced by the Faircloth Amendment to the broader welfare reforms implemented in the Quality Housing and Work Responsibility Act of 1998. This amendment outlawed federal funding for housing authorities who sought to expand their public housing stock.

The term 'social housing,' common in Europe and familiar across the world, has rarely been used in the United States. Yet some scholars argue that the term applies to this country's necessarily hybrid and codependent nature of funding sources for non-profit and publicly owned housing, where it constitutes about 5 percent of total stock (Bratt, 2012). This codependency, along with a political preference for a 'return' of social housing to market rules after a certain time, has also affected efforts to establish non-profit forms of housing provision, both as rental and cooperative developments. For instance, in 1959, New York State's Mitchell Lama program, established only four years prior, abandoned its original goal to keep developments regulated in perpetuity, allowing owners to opt out once the mortgage was paid (Botein, 2009).

For these and many other government programs, the 'household' is the central social unit of measurement. The u.s. Census defines the 'household' architecturally: "A household consists of all the people who occupy a housing unit." This is directly linked to a more circumscribed definition of 'family' (See Martin, Moore, Schindler, 2015). Again citing the U.s. Census, "There are two major categories of households, family and nonfamily." While a "family" is defined as two or more individuals "related by birth, marriage, or adoption and residing together," a "nonfamily household" is defined as a single person living alone or exclusively with non-related others (U.s. Census, 2015). Reading definitions of family and household reminds us that these social constructs 


\section{"In 2015, the average national housing wage for a two-bedroom unit was $\$ 19.35$ while the national minimum wage was $\$ \mathbf{7 . 2 5}$. In other words, a household earning minimum wage would need to work more than two and a half full-time jobs to afford an average two- bedroom rental."}

are also central to our understanding of what is 'decent.' Whether that is considered morally (in terms of who should be cohabiting and what should occur within and between dwellings); in terms of fairness (and access to 'adequate' construction and amenities); or with regard to its implications for public health and the protection of private property (historically the key driver for housing regulations), notions of what is decent have always pertained to what was considered socially acceptable, and thus credit worthy (See Martin, Moore, Schindler, 2015). ${ }^{13}$ As one of the most striking examples, upon their founding as a part of the New Deal, guidelines from the Federal Housing Administration (FHA) to evaluate candidate properties for mortgage insurance stipulated that neighborhoods be racially homogenous. ${ }^{14}$

\section{RACE IN PLACE}

Since the late 1980s, scholars have analyzed housing's relationship to various other basic necessities -from education, to transportation, to employment- in their

13 "Decency" is rarely defined, but is central to many housing programs. From Mayor de Blasio's Housing New York: A Five-Boro, Ten-Year Plan, released in mid-2014: "to make this a city where everyone rises together, and everyone has a safe and decent home." (de Blasio, 2014); or from the City's Housing Quality Standards (HQS) Inspection, administered to all Section 8 housing: "This inspection is required to confirm that a H PD Section 8-subsized apartment is decent, safe, sanitary, and meets minimum physical standards set by the U.S. Department of Housing and Urban Development (HUD)," accessed June 12, 2015, http://www1.nyc.gov/nyc-resources/service/1870/housing-qual- ity-standards-hqs-inspection. See also the Social Science Research Council's "Decent City" initiative: http://citiespapers.ssrc.org/.

14 Among other governmental and non-governmental organizations, the Federal Housing Administration was instrumental in enforcing segregated cities according to not only stylistic and economic criteria, but also racial ones-namely through supporting the practice of redlining and preferential treatment of developments with racially restrictive covenants. This type of institutional discrimination was the primary motivation for the 1968 Fair Housing Act (Stearns, s.d.). For a broader reflection on this matter, see for instance, Jackson, 1995. 
assertion that "place matters." 15 A person's exposure to poverty and crime, or their prospects for health, education, and income, as well as other indicators of 'well-being,' are not only measurable, but predictable, according to the neighborhood in which he or she lives (See Martin, Moore, Schindler, 2015). ${ }^{16}$ The racial dimensions of wealth inequality remain striking and have direct spatial implications as well. In 2013, the median-income white household's net worth was ten times that of the median-income Hispanic household, and 13 times that of the median-income black household. And even with higher incomes, according to a 2015 study, middle-income black households are more likely to live in low-income areas than white households of comparable incomes, turning the primacy of economic inequality on its head (Reardon, Fox and Townsend, 2015).

The principles underlying real estate development play a central role in establishing these relationships. Property taxes collected annually on the assessed value of land and buildings are local governments' single most significant source of revenue for supporting public services. ${ }^{17}$ Accordingly, local

15 William Julius Wilson was among the first to expose how the structural economic changes of the 1970 s and 1980 s, including the declining industrial base of cities, the bifurcated low-wage and high-wage economy, and the geographic shift of jobs to the suburbs, manifested in spatial concentrations of poor, minority communities in inner-city neighborhoods with high rates of unemployment. Because past discrimination had led African Americans to be concentrated in the central-city neighborhoods and manufacturing occupations that were especially hard-hit by economic restructuring, these economic changes had a particularly deleterious impact on this group, whose socio-spatial isolation from the economic mainstream reached critical levels through the movement of middle- and higher-income African American families to the suburbs after the passage of fair housing laws. Wilson argued that this exodus deprived inner-city communities of critical resources and role models (Wilson, 1987). Though emphasizing a different causal mechanism -racial segregation itself rather than middle-class flight- Douglas Massey and Nancy Denton also examined the socioeconomic dislocation and disadvantage associated with growing up in racially segregated areas of concentrated poverty (Massey y Denton, 1993). Following these seminal works, the turn of the century witnessed a burgeoning literature focused on inequality of neighborhood conditions and their impacts on residents' life chances. For a review, see Gould Ellen and Turner, 1997: 833-866. While acknowledging the racial dimension of poverty concentration, many of these subsequent works have focused more broadly on how living and growing up in low-income neighborhoods affects a number of different economic and social outcomes. For example, Dreier, Mollenkopf, and Swanstrom demonstrate how rising economic segregation, combined with jurisdictional fragmentation and the devolution of responsibility for service provision to localities, has left many low-income neighborhoods struggling to provide the services their residents need to survive and get ahead in life (Dreier, et al., 2014). In his comprehensive study of neighborhood effects in Chicago, Robert J. Sampson demonstrated the powerful effect of concentrated poverty on behaviors and outcomes ranging from violence and incarceration to verbal skills and employment chances (Sampson, 2012).

16 As just one example of the renewed interest in studies done around the Moving to Opportunity pilot project, a series of articles were published in The New York Times this year. See, for instance Leonhardt, et al., 2015, and the linked interactive feature published on the same date, "The Best and Worst Places to Grow Up: How Your Area Compares."

17 "[P]roperty tax-based local finance can also produce inequalities, and in particular can produce paths that worsen these inequalities. Consider a distressed city with low property values per person. In order to provide basic services, the city will need to charge very high property tax rates. This in turn could lead businesses (which typically pay more in taxes than they use in services) to migrate away, which in turn reduces the tax base, which in turn worsens services. This leads to an unvirtuous cycle" (Green, 2012: 431) 
real estate values -and not the overall wealth of a city, state, or nation- are one of the clearest predictors of the quality of education, amenities, and safety in U.S. neighborhoods. In turn, the quality of those public services is often the strongest predictor of the real estate prices. In 2010, the average cost of homes near high-achieving public schools in the 100 largest metropolitan areas of the U.S. was 2.4 times higher than those near schools whose achievement was deemed low (Rothwell, 2012).

In this way the housing market distinguishes itself from other markets. Its commodities are fixed; its rootedness in place inextricably links it to vital aspects of life beyond simply providing shelter; its production occurs over extended periods of time and is cost intensive; and there are highly emotional values attached to it. It differs from other sectors of the real estate market through one key factor: for the overwhelming majority of people, participation is not optional, since the result would be homelessness. This last point creates a decided imbalance of power and choice between the providers of housing -developers or large-scale owners- and those needing housing. This imbalance of power within the housing market translates fiscal concerns into material ones, highlighting the necessarily permeable borders that define the set of concerns related to what we call the 'economy.' After all, the root of the word itself, the Greek oikos or household, indicates an interplay of forces at work that reaches beyond a financial frame without negating it. So, upon closer inspection, we recognize that many of the conditions and qualities more conventionally relegated to the world of culture are not simply affected by economic inequality, but rather that they actively assist in its design and reproduction. In this sense, the spaces of house and housing -the oikos- are not just coincidentally instructive examples of inequality; they define it (Foster and Garshick Kleit, 2014). ARQ 
REINHOLD MARTIN

$<$ rm454@columbia.edu>

Architect. PhD, Princeton University (USA, 1999). His publications include The Organizational Complex: Architecture, Media, and Corporate Space (MIT Press, 2003), Utopia's Ghost: Architecture and Postmodernism, Again (Minnesota, 2010), and Multi-National City: Architectural Itineraries (with Kadambari Baxi, Actar, 2007). His book of essays on the contemporary city is forthcoming as The Urban Apparatus: Mediapolitics and the City (Minnesota, 2016). Currently, Martin is working on a history of the American university as a media complex and he is Director of

the Temple Hoyne Buell Center for the Study of American Architecture (Columbia University, USA) and Professor of Architecture at GSAPP

(Columbia University, USA).

\section{JACOB MOORE}

<jrm2031@columbia.edu>

Architect. Master of Science in Critical, Curatorial, and Conceptual Practices in Architecture, GSAPP, Columbia University (USA, 2012). Moore's work has been exhibited internationally and published in various magazines and journals including Artforum, Future Anterior, and the Avery Review (averyreview.com), where he is also a contributing editor. Moore is Assistant Director of the Temple Hoyne Buell Center for the Study of American Architecture (Columbia University, USA).

\section{SUSANNE SCHINDLER}

<susanneschindler@gmail.com>

Dipl.-Ing., University of the Arts, Berlin. Currently completing a $\mathrm{PhD}$ at ETH Zurich. Schindler has taught design at The New School and Columbia University, and writes frequently for journals including Bauwelt, Urban Omnibus, and Places. She is Adjunct Associate Research Scholar at the Temple Hoyne Buell Center for the Study of American Architecture (Columbia University, USA). 


\section{BIBLIOGRAFÍA / BIBLIOGRAPHY}

Aalbers, Manuel; B REt T, Christophers. «Centring Housing in Political Economy,» Housing, Theory and Society 3I, no. 4 (2014)

A S h e n f elt e R, Orley C. «Comparing Real Wages,» NBER Working Paper I80o6 (2012) Accedido I2 de junio 20I5. Disponible en: http://www.nber. org/digest/augI2/wI80o6.html

Berube, Alan; holmes, Natalie «Some Cities Are Still More Unequal than Others-An Update,» Brookings Institute Accedido 2 de junio de 2015. Disponible en: http://www.brookings.edu/research/reports2/2015/o3/ city-inequality-berube-holmes

Bolton, Megan; Bravve, Elina; Miller, Emily; Crowley, Sheila and E R R ICO, Ellen. Out of Reach 2015 (Washington, D.C.: National Low Income Housing Coalition, 20I5) Disponible en: http://nlihc.org/sites/ default/files/oor/Oor_2OI5_FuLL.pdf

вот EıN, Hilary. «New York State Housing Policy in Postwar New York City. The Enduring Rockefeller Legacy,» Journal of Urban History 35, no. 6 (September 2009)

B R AT T, Rachel G. «The Quadruple Bottom Line and Nonprofit Housing Organizations in the United States,» Housing Studies 27, no. 4 (2012)

COLLINSON, Robert; GOULD ELLEN, Ingrid; Jens Ludwig «Low Income Housing Policy,» Marzo I de 2015, accedido 24 de agosto de 2015 Disponible en: http://www.nber.org/chapters/ci3485.pdf.

DE BLASı, Bill. «Housing New York: A Five-Boro, Ten-Year Plan». Mensaje del Alcalde de NY, 20I4. Accedido I2 de junio de 20I5. Disponible en:

http://wwwi.nyc.gov/office-of-the-mayor/news/I99-I4/mayor-de-blasiohousing-new-york--five-borough-Io-year-housing-plan-protect-and\#/o Dreier, Peter; Mollen kopf, John; swans t rom, Todd. Place Matters: Metropolitics for the Twenty-First Century, 3 rd ed. (Lawrence: University Press of Kansas, 2014)

Federal Housing Administration «Underwriting Manual. Underwriting and Valuation Procedure Under Title Il of the National Housing Act,I934». En: ST EAR N S, Richard C, Memorandum. Racial Content of FHA Underwriting Practices, I934-I962. http://archives.ubalt.edu/aclu/pdf/ Plex48.pdf

FOSTER Thomas B.; GARSHIC K KLEIT, Rachel. «The Changing Relationship Between Housing and Inequality, 1980-2010,» Housing Policy Debate 25, no. I (2014)

FRY, Richard; коснна R, Rakesh. «America's Wealth Gap Between Middle-income and Upper-income Families is Widest on Record,» Pew Research Center, I7 de diciembre de 20I4. Accedido 2 de junio 2015. Disponible en: http://www.pewresearch.org/fact-tank/20I4/I2/I7/ wealth-gap-upper-middle-income/

GOUld Ellen, Ingrid; TURNer, Margery Austin. «Do Neighborhoods Matter? Assessing Recent Evidence,» Housing Policy Debate 8, no. 4 (I997) http://www.tandfonline.com/doi/pdf/ro.Io8o/I05II482.I997.952I280 GRE EN, Richard K. «Housing Markets, Prices, and Policies». En: в Rо о к s, Nancy; DoNAGHT Kieran; KNAPP, Gerrit-Jan (eds) The Oxford Handbook of Economics and Planning (New York: Oxford University Press, 2012)

House Housing: An Untimely History of Architecture and Real Estate. Research project conducted by the Temple Hoyne Buell Center for the Study of American Architecture. Disponible en: http://www.house-housing.com IACOViEllo, Matteo. «Housing Wealth and Consuption,» The Federal Reserve Board, International Finance Discussion Papers, no. 1027 (2011) Disponible en: http://www.federalreserve.gov/pubs/ifdp/20II/ı027/ ifdpio27.htm

JAC K S ON, Kenneth. Crabgrass Frontier. The Suburbanization of the United States (New York: Oxford University Press, 1995)

Joint Center for Housing Studies, The State of the Nation's Housing (2010). Disponible en: http://www.jchs.harvard.edu/sites/jchs.harvard.edu/ files/son_april2oro.pdf

KING, Richie; FE R D M AN, Roberto. «How Many Months lt Takes an Average Worker to Make What the cEo Makes in a Hour,» Quartz, diciembre 23, 2013. Accedido 20 de abril de 20I5. Disponible en: http://qz.com/156522/ how-many-months-it-takes-an-average-worker-to-earn- what-the-ceomakes-in-an-hour/

LEONHARDT, David; Cox, Amanda; CAIN MILler, Claire. «The Upshot: An Atlas of Upward Mobility Shows Paths Out of Poverty,» New York Times, 4 de mayo de 2015. Disponible en: http://www.nytimes.com/2015/05/04/ upshot/an-atlas-of-upward-mobility-shows-paths-out-of-poverty.html

MARTIn, Reinhold; Moore, Jacob; Schindler, Susanne (eds.) The Art of Inequality: Architecture, Housing, and Real Estate. A Provisional Report. Ist edition. New York: Buell Center, 20I5.

MASSEy, Douglas; DEN TON, Nancy. American Apartheid. Cambridge, M A Harvard University Press, 1993.

MASSEy, Douglas S.; AL bRIGHT, Len; CASciano Rebecca; DeRICKSON, Elizabeth; KIN SEY, David N. Climbing Mount Laurel: The Struggle for Affordable Housing and Social Mobility in an American Suburb. Princeton: Princeton University Press, 2013.

National Low-Income Housing Coalition, «Affordable Housing is Nowhere to be Found for Millions,» Housing Spotlight 5, no. I (2015)

Office of Management and Budget, «Fiscal Year 2014 Analytical Perspectives of the U.s. Government,» Budget of the us Government, 244. Disponible en: https://www.whitehouse.gov/sites/default/files/omb/budget/fyzor4/ assets/spec.pdf

PIKET TY, Thomas; SAEZ, Emmanuel. «Income Inequality in the United States, I9I3-1998,» The Quarterly Journal of Economics II8, no. I (2003). Tablas y datos actualizados a 2013, accedidos I6 junio de 2015. Disponible en: http://eml.berkeley.edu/ saez/

PIvo, Gary «The Definition of Affordable Housing: Concerns and Related Evidence» (2013) Disponible en: http://www.fanniemae. com/resources/file/fundmarket/pdf/hoytpivo_mfhousing affordablehousingdef_I220I3.pdf.

REARDON, Sean F.; Fox, Lindsay; TownSEND, Joseph. «Neighborhood Income Composition by Race and Income, 1990-2009,» Annals of the American Academy of Political and Social Science 60o, no. I (2015)

RO T HW E L , Jonathan. Housing Costs, Zoning, and Access to High-Scoring Schools. Washington, D.c.: The Brookings Institution, 20I2. Disponible en: http://www.brookings.edu/research/papers/2012/o4/I9-schoolinequality-rothwell

SAM P S ON, Robert J. Great American City: Chicago and the Enduring Neighborhood Effect. Chicago: University of Chicago Press, 2012. Schwa R T , Alex F. Housing Policy in the United States: An Introduction, 2nd ed. New York: Routledge, 2 oro.

National Association of Home Builders (NAHB) Housing's Contribution to Gros Domestic Product (GDP) Accedido I de mayo de 2015. Disponible en: http:// www.nahb.org/en/research/housing-economics/housings-economicimpact/housings-contribution-to-gross-domestic-product-gdp.aspx Stone, Michael E., «What ls Housing Affordability? The Case for the Residual Income Approach». En: TIGHE, J. Rosie and MU E LLER, Elizabeth J. (ed.) The Affordable Housing Reader. New York: Routledge, 2013 U.s. Census. Current Population Survey (CPS). Definitions. Accedido I4 de junio de 20I5. Disponible en: https://www.census.gov/cps/data/ universedefinitions.htm

U.s. Department of Housing and Urban Development, Glossary. Accedido 22 de julio de 2015 (A). http://www.huduser.org/portal/glossary/glossary_a.html

U.s. Department of Housing and Urban Development, FY 2015 HUD Income Limits Briefing Material. Io marzo de 2015. Accedido I4 de julio de 2015 (B). Disponible en: https://www.huduser.gov/portal/datasets/il/ili5/ IncomeLimitsBriefingMaterial_FYI5_Rev_2.pdf

U.s. Department of Housing and Urban Development, Office of Policy Development and Research. The Homeownership Experience of Low-Income and Minority Families: A Review and Synthesis of the Literature (2006) Disponible en: https://www.huduser.gov/portal//Publications/ PDF/hisp_homeowng.pdf

wilson, William Julius. The Truly Disadvantaged: The Inner City, the Underclass, and Public Policy. Chicago: University of Chicago Press, 1987. 